
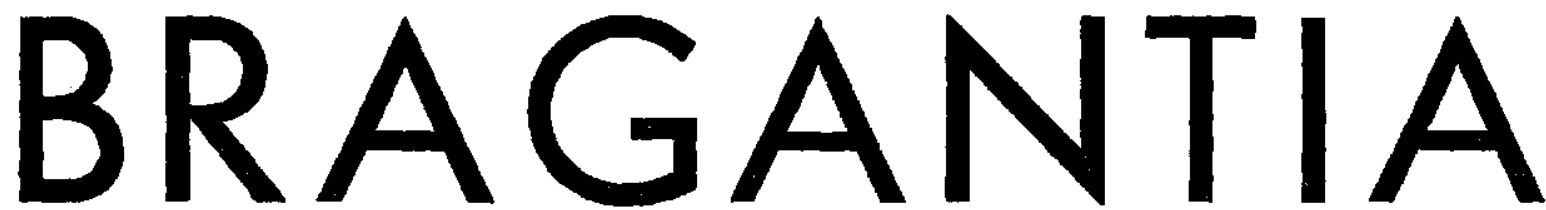

Boletim Técnico do Instituto Agronômico do Estado de São Paulo

Vol. 16

Campinas, outubro de 1957

N. 4

\title{
FEIJOEIRO MANTEIGA, PLANTA-TESTE PARA OS VIRUS DE VIRA-CABEÇA E DA NECROSE BRANCA DO FUMO (*)
}

\author{
A. S. Costa \\ Engenheiro-agrônomo, Seção de Virologia, Instituto Agronômico
}

\section{R E S U M O}

Entre cêrca de 200 variedades de feijoeiro ensaiadas, a Manteiga foi mais sensitiva aos vírus de vira-cabeça e da necrose branca, formando, nas fôlhas primárias, lesões locais adequadas para contagens. Com o vírus de vira-cabeça as lesões locais apareceram de $3-6$ dias após as inoculações, sob a forma de manchas cloróticas, às vêzes com anéis necróticos; com o vírus da necrose branca as lesões se manifestaram em 1- 4 dias, sob a forma de pontuações necróticas, pequenos anéis necróticos ou, em casos de certas estirpes do vírus, como pintas cloróticas.

Feijoeiros com as fôlhas primárias tendo $2 / 3$ de sua expansão ou mais desenvolvidas deram melhores resultados para o vírus de vira-cabeça; para o vírus da necrose branca os melhores resultados foram obtidos com follhas que tinham $2 / 3$ ou ligeiramente menos de sua expansāo total.

O vírus de vira-cabeça não se tornou sistêmico em plantas inoculadas mecânicamente. A maioria das estirpes do vírus da necrose branca também não se tornou sistêmica em feijoeiros inoculados mecânicamente. Uma estirpe amarela dêste tem a capacidade de se tornar sistêmica em feijoeiros sob determinadas conäiçöes.

O sulfito de sódio em solução $0,0125 \mathrm{M}$, usado na extração do inóculo, aumentou ligeiramente o número de lesões formadas nas fôlhas do feijoeiro Manteiga pelo virus de vira-cabeça; aumento consideràvelmente maior foi obtido com a extração em presença de búfer de fosfato $0,1 \mathrm{M}$ com $\mathrm{pH} 7$, sendo êsse efeito atribuído a um aumento da sensitividade da planta-teste. A mistura de ambos causou aumento igual ou ligeiramente menor que o búfer só.

Para o vírus da necrose branca a presença de sulfito de sódio $0,0125 \mathrm{M}$ durante a extração aumentou consideràvelmente o número de lesóes, sendo êsse efeito atribuído à diminuição na perda de atividade do vírus, devida à oxiaação; - búfer sòzinho ocasionou pequeno aumento em comparação com a testemunha, mas a mistura de búfer e sulfito de sódio deu o maior aumento.

(*) Tese de doutoramento apresentada à Escola Superior de Agrícultura "Luiz de Queiroz" da Universidade de São Paulo, em Outubro de 1955.

Recebido para publicaçäo em 26 de julho de 1956. 
O búfer de fosfato de $\mathrm{pH} 7$ ou 8 , adicionado antes da extração do inóculo, ocasionou maior número de lesōes do que o búfer de $\mathrm{pH} 5,3$ ou 6 . Concentrações do búfer de $0,1,0,05,0,025$ e $0,0125 \mathrm{M}$ não causaram grandes diferenças no número de lesões locais, mas as melhores parecem ser 0,05 e 0,025 M.

De quatro concentraçōes de sulfito de sódio ensaiadas, $0,01,0,05,0,025$ e $0,0125 \mathrm{M}$, as duas mais fracas deram os maiores números de lesóes nas plantas inoculadas tanto com o virus de vira-cabeça como com o da necrose branca.

Feijoeiros da variedade Manteiga, mantidos por 48 horas, sob luz reduzida, delam maior número de lesöes locais quando inoculados com o vírus de vira-cabeça do que plantas testemunhas que receberam iluminação normal. $O$ aumento no número de lesöes devido ao condicionamento sob luz reduzida foi menor no caso do virus da necrose branca.

As inoculaçoôs feitas na face superior das fôlhas ocasionaram maior número de lesöes do que quando feitas na face inferior, no caso dos dois vírus.

\section{1 - INTRODUÇÃO}

Os estudos com qualquer vírus de planta, transmissível mecânicamente, são grandemente facilitados quando se dispõe de plantateste que forneça lesões locais adequadas para contagens. Tal planta permite comparações quantitativas entre diferentes preparações do vírus; a fácil determinação de muitas de suas propriedades físicas; o isolamento de estirpes a partir de lesões individuais; a separação do vírus de certas misturas; e, muitas vêzes, a rápida identificação do vírus causador de uma moléstia.

Uma boa planta-teste para as finalidades acima mencionadas deve ser fácil de cultivar em vasos, nas estufas; deve atingir ràpidamente o porte que deverá ter para ser usada, e, além disso, possuir fôlhas uniformes, comparáveis e bem suscetíveis ao vírus. As lesões formadas devem aparecer em poucos dias, ser bem visíveis, isoladas, sem muita tendência para coalescer.

Vira-cabeça $(19,24)$ e a necrose branca (16) são duas das mais importantes moléstias de vírus das plantas no Estado de São Paulo. Ambas têm vasto círculo de hospedeiras, incluindo muitas plantas econômicas e ervas más. O conhecimento do círculo de hospedeiras destas moléstias está sendo constantemente aumentado.

Os estudos feitos com as duas moléstias acima mencionadas; no Instituto Agronômico, sempre se ressentiram da falta de boa planta-teste fornecedora de lesōes locais, embora várias das que têm sido mencionadas na literatura para vírus idênticos ou semelhantes, que ocorrem em outros países, já tenham sido usadas. Nicotiana glutinosa L. (26), N. paniculata L. (15) e Petunia hybrida Vilm. (26), formam lesões locais nas fôlhas inoculadas com o vírus de vira-cabeça (Lethum australiense H.); o guar (Cyamopsis tetragonalobus (L.) Taub.) (20) e o fumo Burley (Nicotiana tabacum L.) (18) formam lesões quando inoculados com o vírus do "tobacco streak" (Annulus orae H.). Tôdas essas plantas-teste têm sido experimentadas neste laboratório, mas nunca foram consideradas inteiramente satisfatórias. 
Em estudos sôbre hospedeiras do vírus do "tobacco streak" no Canadá (5) foi verificado que feijoeiros (Phaseolus vulgaris var. humilis) desenvolviam lesões locais quando inoculados com êsse vírus. Esses resultados foram confirmados posteriormente nos Estados Unidos (20). Nenhum dos autores dêsses trabalhos, entretanto, pareceu considerar o feijoeiro como planta-teste satisfatória para o vírus.

Estudos sôbre o círculo de hospedeiras de vira-cabeça e da necrose branca vêm sendo feitos em Campinas há muitos anos. Numerosas espécies pertencentes a várias famílias foram inoculadas mecânicamente com os vírus causadores destas moléstias. Nenhuma foi encontrada que se tenha mostrado boa planta-teste para lesões locais, embora Beta patellaris Jacq. (11) tenha sido usada com relativo êxito em estudos sôbre o vírus da necrose branca (12). Este vírus representa uma nova variedade do grupo do vírus do "tobacco streak" e receberá oportunamente o nome Annulus orae H. var. florideformans (13). Mais recentemente, variedades de feijoeiro (Phaseolus vulgaris L.) foram experimentadas tendo sido verificado que algumas formavam lesões locais nas fôlhas primárias inoculadas com o vírus da necrose branca. A variedade Manteiga mostrou-se bastante suscetível ao vírus e constituiu surpresa agradável verificar-se que ela era também bastante suscetível ao vírus de vira-cabeça. Posteriormente, uma coleção com mais de 200 variedades (') de feijoeiro foi submetida à inoculação com os dois vírus. Sob o ponto de vista do porte e conformação das fôlhas, outras variedades apresentaram vantagens sôbre a Manteiga mas nenhuma se mostrou tão sensitiva aos dois vírus como esta. Desde então plantas da variedade Manteiga vêm sendo usadas intensivamente em vários experimentos com êstes vírus, tendo se revelado extremamente úteis para trabalhos quantitativos. Algumas fases do trabalho com a variedade Manteiga como planta-teste para êsses dois vírus constituem o assunto dêste trabalho.

\section{2 - MATERIAIS E METODOS}

Os feijoeiros das variedades usadas nos experimentos foram cultivados em vasos de $15 \mathrm{~cm}$ de diâmetro permitindo que $3-4$ plantas crescessem em cada vaso. $\mathrm{Na}$ maioria dos testes feitos com plantas da variedade Manteiga compararam-se dois ou quatro tratamentos, usando-se as quatro meias-fôlhas das duas fôlhas primárias das plantas. A comparação dos tratamentos nas meiasfôlhas foi feita em pares ou então quatro tratamentos foram comparados ao acaso nas quatro meias-fôlhas de cada planta. Na maioria dos ensaios de condicionamento sob luz reduzida compararam-se plantas tratadas com não tratadas. 
O inóculo do vírus de vira-cabeça foi obtido sempre de plantas de fumo recém-infetadas que mostravam sintomas necróticos locais e sistêmicos. Aquêle do vírus da necrose branca foi obtido na maioria dos casos de fôlhas novas de plantas de fumo infetadas, na fase de recuperação.

Em alguns ensaios apenas uma amostra do inóculo foi utilizada. Em outros, para os quais se necessitaram quatro amostras do mesmo inóculo, foram elas preparadas de uma das seguintes maneiras: 1) as fôlhas utilizadas foram cortadas em quatro partes aproximadamente iguais; cada uma destas foi por sua vez cortada em quatro partes, e estas novamente subdivididas em quatro. Prepararam-se então quatro amostras compostas, misturando-se ao acaso cada uma das unidades finais de uma área com cada uma das unidades finais das outras; 2) por meio de um furador de rôlhas pequenos discos de $1 \mathrm{~cm}$ de diâmetro foram tirados das fôlhas que forneceram o inóculo, usando-se então para cada amostra - mesmo número de discos escolhidos ao acaso. A extração do inóculo foi sempre feita esmagando-se a amostra dos tecidos infetados num almofariz, em presença do diluente usado. Este foi em geral adicionado na proporção de $5: 1 \mathrm{em}$ pêso e consistiu, em muitos experimentos, numa mistura de búfer de fosfato $0,05 \mathrm{M}$ com $\mathrm{pH} 7$ mais sulfito de sódio 0,025 ou $0,0125 \mathrm{M}$. Depois de estarem os tecidos bem esmagados foram êles espremidos em um pedaço de pano limpo, obtendo-se assim o liquido a ser utilizado como inóculo.

Os feijoeiros foram usados em inoculações com o vírus de vira-cabeça quando suas fôlhas primárias estavam com cêrca de $2 / 3$ da expansão total ou ligeiramente mais velhas. Para o vírus da necrose branca foram utilizadas plantas que tinham suas fôlhas primárias com $2 / 3$ da expansão total ou ligeiramente mais novas.

Pó fino de carborundo (malha 400) foi sempre polvilhado sôbre as fôlhas a serem inoculadas. A fricção do inóculo nas fôlhas foi feita com pedaços de gaze de $2,5 \times 2,5 \mathrm{~cm}$, ou com o dedo indicador molhado no líquido.

A contagem das lesões foi feita assinalando-se estas com a ponta de um lápis no caso de pequeno número de lesões por fôlha. Quando as lesões eram muito numerosas fêz-se uma estimativa do seu número.

A análise estatística $\left({ }^{2}\right)$ da maioria dos experimentos foi feita determinando-se a variância dos grupos de dados relativos a cada tratamento e determinando-se os limites fiduciais para os totais $(t-10 \%)$. No ensaio em que se comparou o número de lesões produzidas nas faces superior e inferior das fôlhas fêz-se a análise dos dados pareados.

(2) Queremos consignar nossos agradecimentos à Seçāo de Técnica Experimental, do Instituto Agronômico, pela análise estatística dos experimentos. 
Os experimentos com o vírus de vira-cabeça foram efetuados independentemente daqueles com o vírus da necrose branca. Os resultados de experimentos idênticos com os dois vírus foram, entretanto, incluídos nos mesmos quadros para maior facilidade no seu exame e discussão.

\section{3 - RESULTADOS}

\section{1 - SUSCETIBILIDADE DAS VARIEDADES DE FEIJOEIRO AOS DOIS VIRUS}

Mais de 200 variedades de feijoeiro foram ensaiadas quanto à sua suscetibilidade aos vírus de vira-cabeça e da necrose branca. A suscetibilidade (ou sensitividade) das variedades quànto à formação de lesões locais foi bastante variável. Lesões locais características daquelas causadas pelo vírus de vira-cabeça foram observadas em $26 \%$ das variedades de feijoeiro ensaiadas. Apenas três variedades se mostraram bastante sensitivas, sendo estas a Manteiga, Chumbinho 63 e Chumbinho $79\left(^{3}\right)$.

De uma maneira geral as variedades de feijoeiro mostraram-se mais suscetíveis ao vírus da necrose branca do que ao vírus de vira-cabeça. Cêrca de 52\% das variedades apresentaram lesões locais quando inoculadas com o vírus da necrose branca, e delas, as 23 seguintes se mostraram bastante sensitivas: Manteiga, Chumbinho, 180-1-1, Roxinho 23, Roxinho 58, Roxinho 153, 956-Paroto Rey de los Negros, 1272-Bico de Ouro, 1373-SNS Brando, 1400Chumbinho, 1408-Roxinho, 1418-Jalo, 1419-Paco, 1421-Rosinha, 1425-Paquinho Mineiro, 1427-Bico de Ouro, 1428-Mulatinho Lustroso, 1429-Mulatinho Claro, 1430-Mulatinho Rosado, 1431-Chumbinho, 1432-Mulatinho, 1435-Mulatinho, 1437-Mulatinho, 1468-Manteiga.

A variedade Manteiga se mostrou bastante sensitiva tanto ao vírus de vira-cabeça como ao vírus da necrose branca, mas o mesmo não se deu com outras variedades, não tendo havido correlação na suscetibilidade aos dois vírus.

\section{2 - TIPOS DE LESAO LOCAL}

3.2.1. - Vira-cabeça. As lesões locais causadas pelo vírus de vira-cabeça nas fôlhas primárias do feijoeiro Manteiga usualmente aparecem 3 - 6 dias após a inoculação. São manchinhas cloróticas, pequenas a princípio, mas que vão aumentando em tamanho quando se tornam mais velhas (est. $1-A$, est. $2-A$ ). 0 tamanho das lesões varia entre 1 a $4 \mathrm{~mm}$ de diâmetro. Em alguns casos as lesões cloróticas podem ser circundadas por anel necrótico com ou sem pinta necrótica central.

(3) Números das variedades e nomes, constantes do registro da Seçăo de Genética, do Instituto Agronômico. 
3.2.2 - Necrose branca. De $1-4$ dias após a inoculação aparecem as lesões locais nas fôlhas primárias do feijoeiro Manteiga, que foram friccionadas com o inóculo dêste vírus. Primeiramente são lesões necróticas de coloração parda, do tamanho de ponta de alfinete, mas depois crescem atingindo de 1 a $2 \mathrm{~mm}$ de diâmetro (est. 1-B). As lesões são mais distintas em fôlhas que, quando inoculadas, não ultrapassam $2 / 3$ de sua expansão total. Em fôlhas velhas a inoculação produz lesões menos definidas, que passam a ter a forma de anéis, manchas amarelas indefinidas ou outras formas. Foi também notado que a temperatura tem influência sôbre a conformação das lesões causadas por êste vírus no feijoeiro Manteiga. No verão, quando a temperatura nas estufas era bastante elevada, as lesões eram mais da forma de anéis (est. $2-D$ ). No inverno, ou durante períodos frios do ano, as lesões eram do tipo de ponta de alfinete.

A maioria das estirpes comuns do vírus da necrose branca causou os sintomas descritos, mas encontraram-se outras que provocaram sintomas diferentes. Uma delas induz lesões na forma de anéis necróticos muito fracos. Outra estirpe causa apenas pintas cloróticas (est. $2-B$ ), em parte semelhantes àquelas causadas pelo vírus de vira-cabeça.

As lesões locais formadas na maioria das outras variedades que se mostraram suscetíveis ao vírus apresentaram tendência para crescer mais e coalescer, do que aquelas formadas em Manteiga. Dessa maneira deram origem a grandes áreas com necrose do tipo concêntrico ou provocaram a morte de áreas indefinidas das fôlhas.

\section{3 - O VIRUS DE VIRA-CABEÇA NAO SE TORNOU SISTEMICO NAS PLANTAS INOCULADAS MECANICAMENTE E O DA NECROSE BRANCA, SO RARAMENTE}

$O$ vírus de vira-cabeça em nenhum caso se tornou sistêmico nos feijoeiros da variedade Manteiga inoculados mecânicamente, não obstante o número de lesões por fôlha ter sido de 500 ou até mais. Em nenhuma outra variedade também se tornou o vírus sistêmico quando inoculado mecânicamente. Nota-se entretanto, que êsses vírus já foi recuperado de feijoeiros do campo, invadidos sistêmicamente, e que provàvelmente tinham sido infetados por meio do vetor (17).

Da mesma forma que o vírus de vira-cabeça, também as estirpes comuns do vírus da necrose branca não se tornam sistêmicas em feijoeiros Manteiga ou de outras variedades, inoculados mecânicamente. Sabe-se, no entanto, que nos Estados Unidos há um vírus pròximamente relacionado ao da necrose branca, que causa uma moléstia sistêmica do feijoeiro (29). Em São Paulo há uma estirpe amarela do vírus da necrose branca, que se tem tornado 
sistêmica em plantas dessa variedade. Quando sistêmicamente invadidos os feijoeiros mostraram necrose severa.

Mesmo as estirpes comuns do vírus da necrose branca podem, em certas ocasiões, causar necrose ao longo do pecíolo da fôlha e no ponto de inserção daquele na haste. Se a necrose fôr severa nesse ponto, pode ocasionar a morte daquela parte da planta situada acima da inserção do pecíolo na haste.

\section{4 - JNFLUENCIA DOS TRATAMENTOS APLICADOS AO INOCULO OU A PLANTA-TESTE SOBRE O NÚMERO DE LESOES LOCAIS}

3.4.1 - Extração do inóculo em presença de vários diluentes. O efeito de diluentes, adicionados aos tecidos infetados na ocasião em que o inóculo é preparado, foi comparado em uma série de ensaios. Usaram-se como diluentes a água destilada, o búfer de fosfato $0,1 \mathrm{M}$ com $\mathrm{pH} 7$, o sulfito de sódio $0,01 \mathrm{M}$ e uma mistura de búfer com sulfito de sódio. Os resultados de seis ensaios com cada um dos dois vírus estão apresentados no quadro 1 . Eles

QuAdro 1.-Efeito de vários diluentes, adicionados na extração dos vírus de viracabeça e da necrose branca, sôbre o número de lesões locais produzidas em de fôlhas de feijoeiro Manteiga

\begin{tabular}{|c|c|c|c|c|c|c|c|c|}
\hline \multirow{3}{*}{$\begin{array}{l}\text { N.o } \\
\text { Ensaio }\end{array}$} & \multicolumn{8}{|c|}{$\begin{array}{l}\text { Lesōes formadas em } 12 \text { meias-fôlhas das plantas-teste quando o inóculo foi } \\
\text { extraido em presença dos diluentes abaixo indicados }\end{array}$} \\
\hline & \multicolumn{4}{|c|}{ Vira-cabeça } & \multicolumn{4}{|c|}{ Necrose branca } \\
\hline & $\begin{array}{l}\text { águr } \\
\text { desti- } \\
\text { lada }\end{array}$ & $\begin{array}{l}\text { búfer } \\
\text { pH T } \\
0,1 \text { M }\end{array}$ & $\begin{array}{l}\text { sulfito } \\
\text { de sódio } \\
0,01 \mathrm{M}\end{array}$ & $\begin{array}{l}\text { búfer } \\
\text { mais } \\
\text { sulfito }\end{array}$ & $\begin{array}{l}\text { água } \\
\text { desti- } \\
\text { lada }\end{array}$ & $\begin{array}{l}\text { búfer } \\
\text { pH } 7 \\
0,1 \quad \text { M }\end{array}$ & $\begin{array}{c}\text { sulfito } \\
\text { de sódio } \\
0,01 \mathrm{M}\end{array}$ & $\begin{array}{c}\text { búfer } \\
\text { mais } \\
\text { sulfito }\end{array}$ \\
\hline 1 & $\begin{array}{l}\quad 6 \\
\pm \quad 6,2\end{array}$ & $\begin{array}{r}526 \\
\pm \quad 172\end{array}$ & $\begin{array}{l}8 \\
\pm \quad 8,5\end{array}$ & $\begin{array}{r}489 \\
\pm \quad 173\end{array}$ & 0 & $\begin{array}{r}228 \\
\pm \quad 74\end{array}$ & $\begin{array}{r}2800 \\
\pm \quad 766\end{array}$ & $\pm \begin{array}{r}3950 \\
486\end{array}$ \\
\hline 2 & $\begin{array}{r}49 \\
\pm \quad 18\end{array}$ & $\begin{array}{r}2480 \\
\pm \quad 344\end{array}$ & $\begin{array}{r}1537 \\
\pm \quad 526\end{array}$ & $\begin{array}{r}2520 \\
\pm \quad 518\end{array}$ & 0 & $\begin{array}{r}56 \\
\pm \quad 42\end{array}$ & $\begin{array}{r}212 \\
\pm \quad 133\end{array}$ & $\begin{array}{r}3050 \\
\pm \quad 449\end{array}$ \\
\hline 3 & $\begin{aligned} 11 \\
\pm\end{aligned}$ & $\begin{array}{r}425 \\
\pm \quad 87\end{array}$ & $\begin{array}{r}44 \\
\pm \quad 27\end{array}$ & $\begin{array}{r}133 \\
\pm \quad 48\end{array}$ & 0 & 0 & $\begin{array}{ll} & 410 \\
- & 160\end{array}$ & $\begin{array}{r}2850 \\
\pm \quad 408\end{array}$ \\
\hline & $\begin{array}{r}73 \\
\pm \quad 37\end{array}$ & $\begin{array}{r}2313 \\
\pm \quad 521\end{array}$ & $\begin{array}{r}418 \\
\pm \quad 148\end{array}$ & $\begin{array}{r}400 \\
\pm \quad 80\end{array}$ & 0 & $\begin{array}{l}6 \\
\pm \quad 6,2\end{array}$ & $\begin{array}{r}859 \\
-\quad 313\end{array}$ & $\begin{array}{r}1740 \\
\pm \quad 526\end{array}$ \\
\hline 5 & $\begin{array}{r}52 \\
\pm \quad 31\end{array}$ & $\begin{array}{r}3300 \\
\pm \quad 363\end{array}$ & $\begin{array}{r}247 \\
\pm \quad 149\end{array}$ & $\begin{array}{r}1970 \\
\pm \quad 457\end{array}$ & o & $\begin{array}{r}37 \\
\pm \quad 19\end{array}$ & $\begin{array}{r}1270 \\
\pm \quad 356\end{array}$ & $\begin{array}{r}3950 \\
\pm \quad 247\end{array}$ \\
\hline & $\begin{array}{r}955 \\
\pm \quad 404\end{array}$ & $\begin{array}{r}3505 \\
\pm 1070\end{array}$ & $\begin{array}{r}1879 \\
\pm \quad 613\end{array}$ & $\begin{array}{r}3832 \\
\pm \quad 790\end{array}$ & 0 & $\begin{array}{r}149 \\
\pm \quad 56\end{array}$ & $\begin{array}{r}1780 \\
\pm \quad 310\end{array}$ & $\begin{array}{r}3100 \\
\pm \quad 416\end{array}$ \\
\hline Média & 191,0 & 2091,5 & 688,8 & 1557,3 & 0 & 79,3 & 1220,3 & 3023,3 \\
\hline
\end{tabular}

indicam que o inóculo do vírus de vira-cabeça extraído em presença de água destilada causou em geral pequeno número de lesões. Extraído com sulfito de sódio $0,01 \mathrm{M}$, causou maior número de lesões locais do que com água destilada, mas maior aumento foi 
obtido quando se usou como diluente o búfer de fosfato $0,1 \mathrm{M}$, com pH 7. A mistura de búfer com sulfito de sódio aumentou grandemente o número de lesões locais quando comparada com extração em água destilada, mas o aumento obtido pela interação dos dois diluentes foi em média ligeiramente menor do que aquêle produzido só pelo búfer.

$\mathrm{O}$ vírus da necrose branca extraído com água destilada ùnicamente não causou qualquer lesão local nas fôlhas de feijoeiro Manteiga. Quando inóculo comparável foi extraído com búfer de fosfato $0,1 \mathrm{M}$ de $\mathrm{pH} 7$, algumas lesões foram obtidas. O inóculo extraído com sulfito de sódio $0,01 \mathrm{M}$ causou grande número de lesões. A mistura búfer mais sulfito causou ainda maior número de lesões.

3.4.2 - Influência do $\mathrm{pH}$ do búfer de fosfato. O efeito do $\mathrm{pH}$ de vários sistemas de búfers sôbre os vírus de plantas tem sido estudado por vários autores $(22,27,28)$. Best \& Samuel (9) fizeram êstes estudos com o vírus do "tomato spotted wilt" na Austrália, que é semelhante ao vírus de vira-cabeça que ocorre no Brasil.

Nos presentes ensaios estudou-se apenas a influência do $\mathrm{pH}$ do búfer de fosfato quando o inóculo foi extraído em presença dêste e inoculado logo após, sem ajustamento posterior.

Os búfers foram preparados usando-se diferentes proporções de $\mathrm{Na}_{2} \mathrm{HPO}_{4}$ e $\mathrm{KH}_{2} \mathrm{PO}_{4}(10)$ para se obter quatro níveis: $\mathrm{pH} \mathrm{5}, 3$ 6,7 e 8 . Amostras de fôlhas infetadas por vira-cabeça e pela necrose branca foram extraídas separadamente em presença dos búfers com os diferentes $\mathrm{pH}$. A cada uma das preparações do vírus da necrose branca adicionou-se a mesma quantidade de sulfito de sódio para que a concentração dêste atingisse $0,0125 \mathrm{M}$. Com o vírus de vira-cabeça não se adicionou sulfito de sódio.

Com cada um dos vírus ensaiados fizeram-se quatro provas, em épocas diferentes. Os resultados destas estão apresentados no quadro 2. Êles indicam que as preparações dos dois vírus obtidos por extração do inóculo em presença de búfers de $\mathrm{pH} 7$ e 8 deram maior número de lesões do que quando extraídos com búfers de $\mathrm{pH}$ 5,3 e 6 . Não houve diferença significativa entre os resultados obtidos com os búfers de $\mathrm{pH} 7$ e 8 .

3.4.3. - Concentração do búfer de fosfato. O efeito comparativo de várias concentrações de búfer de fosfato $(14,22)$ e de soluções de fosfato de potássio (28) em relação ao número de lesões locais produzidas em plantas-teste já foi estudado por alguns autores para outros vírus.

Nos presentes ensaios procurou-se verificar qual o efeito de quatro concentrações do búfer de fosfato com $\mathrm{pH} 7$, quando usadas para extração dos vírus de vira-cabeça e da necrose branca e 
inoculadas em fôlhas de feijoeiros Manteiga. As concentrações ensaiadas foram as seguintes: $0,1,0,05,0,025$, e. $0,0125 \mathrm{M}$. Nos ensaios com o vírus da necrose branca adicionou-se sulfito de sódio às várias concentrações de búfer para atingir a concentração de $0,0125 \mathrm{M}$. Nos ensaios com o vírus de vira-cabeça não foi adicionado sulfito de sódio.

QUADRo 2--Efeito do pH do búfer de fosfato usado na extração do inóculo, sôbre o número de lesões locais produzidas em fôlhas de feijoeiro Manteiga.

\begin{tabular}{|c|c|c|c|c|c|c|c|c|}
\hline \multirow{3}{*}{$\begin{array}{c}\text { Ensaio } \\
\text { N.o }\end{array}$} & \multicolumn{8}{|c|}{$\begin{array}{l}\text { Lesões formadas em } 12 \text { meias-fôlhas das plantas-teste quando o inóculo foi } \\
\text { extraído em presença de búfer de fosfato } 0,05 \mathrm{M} \text { com os } \mathrm{pH} \text { indicados }\end{array}$} \\
\hline & \multicolumn{4}{|c|}{ Vira-cabeça } & \multicolumn{4}{|c|}{ Necrose branca (*) } \\
\hline & 5,3 & 6,0 & 7,0 & 8,0 & 5,3 & 6,0 & 7,0 & 8,0 \\
\hline $1 \ldots$ & $\begin{array}{r}155 \\
\pm \quad 47\end{array}$ & $\pm \begin{array}{r}143 \\
40\end{array}$ & $\begin{array}{r}1425 \\
\pm \quad 614\end{array}$ & $\begin{array}{r}1470 \\
\pm \quad 343\end{array}$ & $\begin{array}{r}195 \\
\pm \quad 56\end{array}$ & $\begin{aligned} & 397 \\
\pm & 170\end{aligned}$ & $\begin{array}{r}1850 \\
\pm \quad 539\end{array}$ & $\begin{array}{r}2020 \\
\pm 526\end{array}$ \\
\hline 2 . & $\begin{array}{r}144 \\
\pm \quad 89\end{array}$ & $\begin{array}{r}320 \\
+253\end{array}$ & $\begin{array}{r}3250 \\
\pm \quad 337\end{array}$ & $\begin{array}{r}3520 \\
\pm \quad 338\end{array}$ & $\begin{aligned} & 750 \\
\pm & 301\end{aligned}$ & $\begin{array}{r}525 \\
\pm 183\end{array}$ & $\begin{array}{r}3530 \\
\pm \quad 248\end{array}$ & $\begin{array}{r}1220 \\
\pm \quad 247\end{array}$ \\
\hline $3 \ldots$ & $\begin{array}{r}428 \\
\pm \quad 65\end{array}$ & $\begin{array}{r}556 \\
\pm 139\end{array}$ & $\begin{array}{r}3220 \\
\pm \quad 293\end{array}$ & $\begin{array}{r}2210 \\
\pm \quad 497\end{array}$ & $\begin{array}{r}188 \\
\pm 100\end{array}$ & $\begin{array}{r}111 \\
\pm \quad 46\end{array}$ & $\begin{array}{r}990 \\
+\quad 343\end{array}$ & $\begin{array}{r}1060 \\
\pm \quad 305\end{array}$ \\
\hline 4 & $\begin{array}{r}47 \\
+\quad 37\end{array}$ & $\begin{array}{r}154 \\
\pm 117\end{array}$ & $\begin{array}{r}1150 \\
+\quad 264\end{array}$ & $\begin{array}{r}1690 \\
\pm \quad 291\end{array}$ & $\begin{array}{r}660 \\
+\quad 355\end{array}$ & $\begin{array}{r}626 \\
+\quad 498\end{array}$ & $\begin{array}{r}3650 \\
+\quad 247\end{array}$ & $\begin{array}{r}3300 \\
+\quad 281\end{array}$ \\
\hline Média & 193,5 & 293,2 & 2261,2 & 2222,5 & 448,2 & 414,7 & 2505,0 & 1900,0 \\
\hline
\end{tabular}

(*) Nos testes com o vírus da necrose branca foi adicionado sulfito de sódio 0,0125 $\mathrm{M}$ aos vários búfers.

Os resultados de quatro ensaios com cada um dos dois vírus estão no quadro 3. Eles indicam que os efeitos das concentrações do búfer de fosfato entre os limites ensaiados não diferiram grandemente entre si. Há, entretanto, ligeira tendência para que as concentrações 0,05 e $0,025 \mathrm{M}$ sejam ligeiramente melhores de que as outras. Êsse efeito foi notado no caso de inoculação tanto do vírus de vira-cabeça como no da necrose branca.

$\mathrm{O}$ búfer de fosfato $0,1 \mathrm{M}$ pode causar danos às fôlhas, especialmente se elas não forem lavadas logo após a inoculação.

3.4.4 - Concentração do sulfito de sódio. O efeito do sulfito de sódio 0,01 M adicionado na extração do inóculo foi de muito maior importância para o vírus da necrose branca do que para o vírus de vira-cabeça. Sem êsse agente redutor as preparações do vírus da necrose branca não mostraram nenhuma atividade ou esta foi reduzidíssima. A extração do vírus de vira-cabeça em presença de sulfito de sódio também resultou em maior atividade quando medida pelo número de lesões locais produzidas pela preparação. 
Em virtude do efeito favorável do sulfito de sódio $0,01 \mathrm{M}$ sôbre a atividade das preparações dos dois vírus em estudo, efetuaram-se alguns ensaios para verificar a influência relativa de diferentes concentrações dêste agente redutor.

Cinco ensaios foram feitos com cada um dos vírus, estudandose o efeito de quatro concentrações de sulfito de sódio: $0,1,0,05$, 0,025 e $0,0125 \mathrm{M}$. Estas soluções de sulfito foram feitas com búfer de fosfato $0,05 \mathrm{M}$, com $\mathrm{pH} 7$.

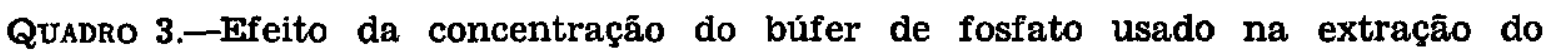
inóculo sôbre o número de lesões locais produzidas em fôlhas de feijoeiro Manteiga

\begin{tabular}{|c|c|c|c|c|c|c|c|c|}
\hline \multirow{3}{*}{$\begin{array}{l}\text { Ensaio } \\
\text { N." }\end{array}$} & \multicolumn{8}{|c|}{$\begin{array}{l}\text { Lesöes formadas em } 12 \text { meias-fîlhas dus plantasteste, quando o inóculo foi extraído } \\
\text { em presença de búfer com pH } 7,0 \text { da concentraçäo molar (*) abaixo indicada. }\end{array}$} \\
\hline & \multicolumn{4}{|c|}{ Vira-cabeça } & \multicolumn{4}{|c|}{ Necrose branca } \\
\hline & 0,1 & 0,05 & 0,025 & 0,0125 & 0,1 & 0,05 & 0,025 & 0,0125 \\
\hline $1 \ldots$ & $\begin{array}{r}270 \\
\pm \quad 109\end{array}$ & $\begin{array}{r}264 \\
\pm \quad 77\end{array}$ & $\begin{array}{r}409 \\
\pm \quad 82\end{array}$ & $\pm \quad 44$ & $\begin{array}{r}3250 \\
\pm \quad 362\end{array}$ & $\begin{array}{r}2950 \\
\pm \quad 449\end{array}$ & $\begin{array}{r}2880 \\
\pm \quad 514\end{array}$ & $\begin{array}{r}2650 \\
+\quad 362\end{array}$ \\
\hline . . & $\begin{array}{r}279 \\
+\quad 103\end{array}$ & $\begin{array}{r}480 \\
\pm \quad 138\end{array}$ & $\begin{array}{r}404 \\
+\quad 92\end{array}$ & $\begin{array}{r}203 \\
\pm \quad 109\end{array}$ & $\begin{array}{r}2900 \\
\pm \quad 292\end{array}$ & $\begin{array}{r}3400 \\
\pm \quad 484\end{array}$ & $\begin{array}{r}3800 \\
+\quad 502\end{array}$ & $\begin{array}{r}2650 \\
\pm \quad 386\end{array}$ \\
\hline $3 \ldots \ldots$ & $\begin{array}{r}1115 \\
\pm \quad 196\end{array}$ & $\begin{array}{r}3270 \\
\pm \quad 372\end{array}$ & $\begin{array}{r}2970 \\
\pm \quad 440\end{array}$ & $\begin{array}{r}1390 \\
+\quad 314\end{array}$ & $\begin{array}{r}2530 \\
+\quad 515\end{array}$ & $\begin{array}{r}2700 \\
\pm \quad 387\end{array}$ & $\begin{array}{r}2710 \\
+\quad 525\end{array}$ & $\begin{array}{r}2480 \\
+\quad 455\end{array}$ \\
\hline $4 \ldots \ldots$ & $\begin{array}{r}540 \\
\pm \quad 181\end{array}$ & $\begin{array}{r}1100 \\
\pm \quad 238\end{array}$ & $\begin{array}{r}1070 \\
\pm \quad 267\end{array}$ & $\begin{array}{r}435 \\
+\quad 124\end{array}$ & $\begin{array}{r}2060 \\
\pm \quad 273\end{array}$ & $\begin{array}{r}2700 \\
+\quad 281\end{array}$ & $\begin{array}{r}3250 \\
+\quad 522\end{array}$ & $\begin{array}{r}2580 \\
\pm \quad 502\end{array}$ \\
\hline Média . . & 551,0 & 1278.5 & 1213,2 & 518,0 & 2685,0 & 2937,5 & 3160.0 & 2590 \\
\hline
\end{tabular}

(*) Nos ensaios com o vírus da necrose branca foi adicionado sulfito de sódio $0,0125 \mathrm{M}$ às várias concentrações do búfer.

Os resultados dos ensaios efetuados estão reproduzidos no quadro 4. t̂les mostram que as concentrações mais favoráveis foram as mais baixas, 0,025 e $0,0125 \mathrm{M}$, não tendo havido diferença significativa entre elas. Estas duas concentrações foram, entretanto, significantemente melhores do que as duas mais fortes. Entre estas duas também não houve diferença significativa.

Concentrações fortes de sulfito de sódio podem também danificar as fôlhas inoculadas, principalmente se elas não forem lavadas imediatamente após a inoculação.

3.4.5 - Influência do desenvolvimento das fôlhas primárias na ocasião da inoculação. A finalidade dêstes ensaios foi verificar a influência do desenvolvimento das fôlhas primárias do feijoeiro Manteiga sôbre a sua sensitividade aos vírus de vira-cabeça e da necrose branca. 
Os feijoeiros usados foram plantados em seis dias consecutivos. Nove dias após o último plantio, quando as fôlhas primárias das plantas mais novas tinham cêrca de $1 / 3$ de sua expansão total, foram tôdas inoculadas com a mesma preparação. Nessa ocasião

QUADRo 4--Efeito sôbre o número de lesões locais prođuzidas em fôlhas de feijoeiro Manteiga, de várias concentraçóes de sulfito de sódio em búfer de fosfato $0,05 \mathrm{M}$ com $\mathrm{pH} 7$, usado na extração do inóculo dos vírus de viracabeça e da necrose branca

\begin{tabular}{|c|c|c|c|c|c|c|c|c|}
\hline \multirow{3}{*}{$\begin{array}{l}\text { Ensaio } \\
\text { N.". }\end{array}$} & \multicolumn{8}{|c|}{$\begin{array}{l}\text { Número de lesões obtidas em } 12 \text { meias-fôlhas, quando o inóculo foi extraído em } \\
\text { presença de bufer mais sulfito de sódio nas concentraços molares indieadas }\end{array}$} \\
\hline & \multicolumn{4}{|c|}{ Vira-cabeça } & \multicolumn{4}{|c|}{ Necrose branca } \\
\hline & 0,1 & 0,05 & 0,025 & 0,0125 & 0,1 & 0,05 & 0,025 & 0,0125 \\
\hline 1. & $\begin{array}{r}267 \\
\pm \quad 64\end{array}$ & $\begin{array}{r}1201 \\
\pm \quad 247\end{array}$ & $\begin{array}{r}1864 \\
+\quad 233\end{array}$ & $\begin{array}{r}2589 \\
+\quad 640\end{array}$ & $\begin{array}{r}585 \\
+\quad 274\end{array}$ & $\begin{array}{r}1850 \\
+\quad 247\end{array}$ & $\begin{array}{r}2900 \\
+\quad 320\end{array}$ & $\begin{array}{r}3150 \\
\pm \quad 378\end{array}$ \\
\hline 2 & $\begin{array}{r}48 \\
\pm \quad 23\end{array}$ & $\begin{array}{r}200 \\
+\quad 81\end{array}$ & $\begin{array}{r}258 \\
+\quad 100\end{array}$ & $\begin{array}{r}337 \\
\pm \quad 134\end{array}$ & $\begin{array}{r}890 \\
+\quad 310\end{array}$ & $\begin{array}{r}2380 \\
\pm \quad 421\end{array}$ & $\begin{array}{r}2730 \\
+\quad 290\end{array}$ & $\begin{array}{r}2600 \\
+\quad 359\end{array}$ \\
\hline 3. & $\begin{array}{r}43 \\
\pm \quad 24\end{array}$ & $\begin{array}{r}263 \\
\pm \quad 123\end{array}$ & $\begin{array}{r}628 \\
\pm \quad 206\end{array}$ & $\begin{array}{r}780 \\
\pm \quad 243\end{array}$ & $\begin{array}{r}1055 \\
+\quad 502\end{array}$ & $\begin{array}{r}1150 \\
+\quad 439\end{array}$ & $\begin{array}{r}2100 \\
+\quad 539\end{array}$ & $\begin{array}{r}1670 \\
\pm \quad 480\end{array}$ \\
\hline 4 & $\begin{array}{r}546 \\
+\quad 272\end{array}$ & $\begin{array}{r}601 \\
\pm \quad 270\end{array}$ & $\begin{array}{r}1124 \\
: \quad 494\end{array}$ & $\begin{array}{r}1761 \\
+\quad 705\end{array}$ & $\begin{array}{r}1162 \\
\pm \quad 299\end{array}$ & $\begin{array}{r}2011 \\
\pm \quad 437\end{array}$ & $\begin{array}{r}2977 \\
+\quad 440\end{array}$ & $\begin{array}{r}3404 \\
\pm \quad 926\end{array}$ \\
\hline $5 \ldots$ & $\begin{aligned} & 365 \\
\pm & 123\end{aligned}$ & $\begin{array}{r}1160 \\
281\end{array}$ & $\begin{array}{r}1381 \\
+\quad 339\end{array}$ & $\begin{array}{r}1325 \\
\pm \quad 250\end{array}$ & $\begin{array}{r}1433 \\
\pm \quad 343\end{array}$ & $\begin{array}{r}3334 \\
\pm \quad 442\end{array}$ & $\begin{array}{r}3369 \\
+\quad 609\end{array}$ & $\begin{array}{r}4801 \\
+\quad 384\end{array}$ \\
\hline Mérlia & 253,8 & 685,0 & 1111,0 & 1348,4 & 1025,0 & 2145,0 & 2815,2 & $31 \geq 5,0$ \\
\hline
\end{tabular}

as plantas das séries mais velhas já tinham fôlhas primárias completamente desenvolvidas. Os resultados dos ensaios estão no quadro 5. Êles mostram que no caso do vírus de vira-cabeça as fôlhas mais velhas apresentaram tendência para desenvolver maior número de lesões do que as mais novas. Para êste vírus as fôlhas primárias com $2 / 3$ de sua expansão total ou pouco mais velhas foram mais sensitivas. Resultados dos outros ensaios, entretanto, têm indicado que as fôlhas primárias das plantas-teste não devem ser demasiadamente velhas, porque então diminui grandemente sua suscetibilidade.

Dentro dos limites de idade utilizados, não houve grande diferença no número de lesões locais formadas nas plantas dos seis grupos inoculados com o vírus da necrose branca. Houve, entretanto, tendência para que as fôlhas mais novas fôssem mais sensitivas. Foi notado em muitos ensaios que as fôlhas primárias com $2 / 3$ de sua expansão total ou ligeiramente mais novas, davam melhores resultados, sendo as lesões mais distintas e fáceis de contar. 
3.4.6 - Condicionamento das plantas-teste sob luz reduzida. A influência do pré-condicionamento das plantas-teste em luz reduzida, sôbre o número de lesões locais obtidas pela inoculação dos vírus de vira-cabeça e da necrose branca, foi estudada nestes ensaios. $O$ pré-condicionamento foi feito sob bancas em estufas, cnde a luminosidade era muito reduzida, as plantas testemunhas

Quadro 5.-Efeito da idade da planta sôbre o número de lesóes locais produzidas pelos vírus de vira-cabeça e da necrose branca em fôlhas de feijoeiro Manteiga

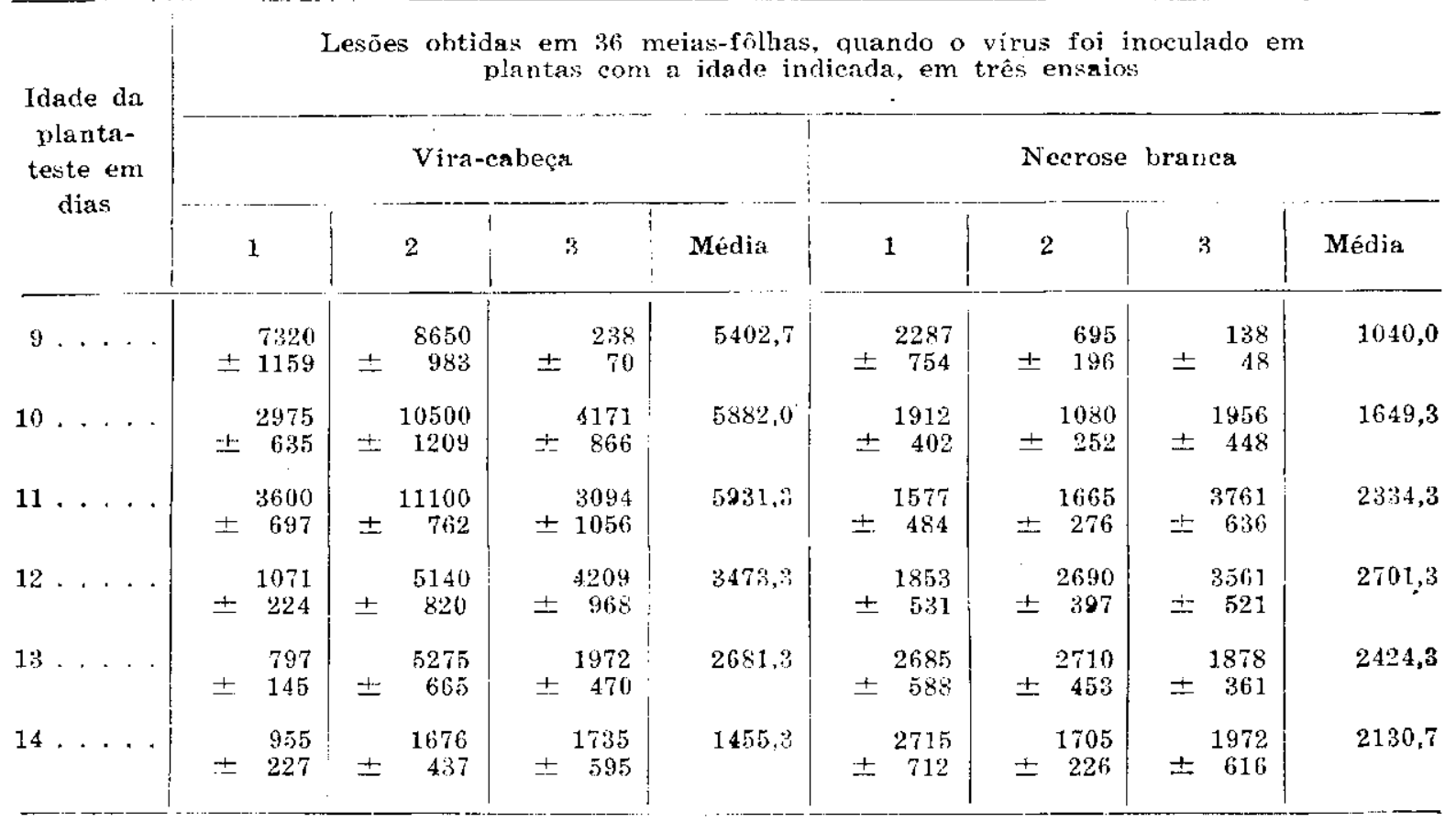

permanecendo sôbre as bancas, onde também, após a inoculação, tôdas as plantas foram colocadas. Os resultados dos ensaios estão no quadro 6.

No caso do vírus de vira-cabeça o aumento da sensitividade das fôlhas primárias do feijoeiro Manteiga foi maior. $O$ número de lesões, obtidas em plantas pré-condicionadas, foi duas a três vêzes maior do que aquêle nos contrôles. No caso do vírus da necrose branca houve aumento no número de lesões nas fồlhas submetidas ao pré-condicionamento em alguns ensaios, mas de una maneira geral as diferencas foram menores.

Em outro experimento, em lugar de submeter as plantas inteiras ao pré-condicionamento, cobriu-se (com saquinhos de papel prêto) apenas uma das fôlhas primárias de cada planta, permanecendo a outra fôlha exposta à luz, como contrôle. Tais plantas foram conservadas em estufas e então inoculadas após 24 a 48 horas. Os resultados estão no quadro 7 . Êles indicam que tanto no caso de vira-cabeça como no da necrose branca houve um aumen- 
to no número de lesões devido ao condicionamento por 48 horas. 0 condicionamento por 24 horas não teve efeito para o vírus de vira-cabeça, mas promoveu um aumento no caso do vírus da necrose branca. Notou-se que as fôlhas primárias cobertas com saco prêto ficaram menores do que as fôlhas opostas (contrôle).

QUADRO 6.-Fifeito do condicionamento das plantas-teste sob luz reduzida, antes da inoculação, sôbre o número de lesóes locais formadas nas fôlhas primárias do feijoeiro Manteiga

\begin{tabular}{|c|c|c|c|c|c|c|}
\hline \multirow{3}{*}{$\begin{array}{c}\text { Ensaio } \\
\text { No }\end{array}$} & \multicolumn{6}{|c|}{$\begin{array}{c}\text { Número de lesões locais formadas em } 36 \text { meias-fôlhas das plantas inoculadas } \\
\text { e submetidas ao tratamento indicado }\end{array}$} \\
\hline & \multicolumn{3}{|c|}{ Vira-cabeça } & \multicolumn{3}{|c|}{ Necrose branca } \\
\hline & contrôle & luz & $\begin{array}{l}\text { aumento devido } \\
\text { \&o } \\
\text { condicionamento }\end{array}$ & contrôle & $\begin{array}{l}\text { luz } \\
\text { reduzida }\end{array}$ & $\begin{array}{l}\text { aumento devido } \\
\text { ao } \\
\text { condicionamento }\end{array}$ \\
\hline $1 \ldots \ldots$ & 3775 & 9400 & $5625 * *$ & 4330 & 4850 & 620 \\
\hline $2 \ldots \ldots$ & 4255 & 10025 & $5770^{* *}$ & 6070 & 5700 & -370 \\
\hline 3 & 2695 & 2980 & 285 & 4580 & 5845 & 765 \\
\hline 4 & 4514 & 8680 & $4166 * *$ & 4020 & 6130 & $2110 * *$ \\
\hline $5 \ldots$ & 2491 & 9090 & $6599 * *$ & 3260 & 5680 & $2420 * *$ \\
\hline Média & 3546,0 & 8035,0 & & 4452,0 & 5541,0 & \\
\hline
\end{tabular}

QUADRo 7.-Efeito do condicionamento das fôlhas primárias do feijoeiro Manteiga com papel prêto, sôbre o número de lesões locais produzidas pelos vírus de vira-cabeça e da necrose branca

\begin{tabular}{c|r|r|r|r|r}
\hline $\begin{array}{c}\text { Duração } \\
\text { do } \\
\text { trata- } \\
\text { mento }\end{array}$ & \multicolumn{3}{|c|}{ Número de lesóes formadas em 12 meias-fôlhas das plantas inoculadas e } \\
submetidas ao tratamento indicado
\end{tabular}

3.4.7 - Comparação da inoculação feita nas faces inferior e superior da fôlha. As duas faces de uma fôlha podem diferir em sua suscetibilidade a determinados vírus, produzindo número de lesões locais diferente quando a inoculação é feita mecânicamente. Essa diferença entre as duas faces pode resultar de variações de 
suscetibilidade dos tecidos pròpriamente ditos ou do efeito sôbre a suscetibilidade, do ambiente diferente a que estão sujeitas. A diferença em suscetibilidade quando medida pelo número de lesões locais produzidas poderia ainda resultar da maior ou menor facilidade com que ambos os lados da fôlha podem ser inoculados.

Quatro ensaios foram feitos com a finalidade de se verificar, no caso do feijoeiro Manteiga, se havia diferença na suscetibilidade, aos vírus de vira-cabeça e da necrose branca, entre as duas faces da fôlha. A inoculação da face superior foi feita da maneira usual, apenas na metade direita, após ter sido polvilhada com carborundo; em seguida à inoculação de cada meia-fôlha na sua face superior, torceu-se a fôlha de modo que a meia-fôlha da esquerda ficasse do lado direito, com a face inferior voltada para cima. Essa metade foi então polvilhada com carborundo e inoculada. Os resultados de quatro ensaios com cada um dos dois vírus estão no quadro 8.

QUADRo.8.-Comparação entre o número de lesões formadas quando os virus de vira-cabeça e da necrose branca foram inoculados na face inferior e superior de fôlhas de feijoeiro Manteiga

\begin{tabular}{|c|c|c|c|c|c|c|}
\hline \multirow{3}{*}{$\begin{array}{c}\text { Ensaio } \\
\text { N.o }\end{array}$} & \multicolumn{6}{|c|}{$\begin{array}{c}\text { Número de lesōes obtidas em } 36 \text { meias-fôlhas, quando o vírus foi } \\
\text { inoculado na face indicada da fôlha }\end{array}$} \\
\hline & \multicolumn{3}{|c|}{ Vira-cabeça } & \multicolumn{3}{|c|}{ Necrose branca } \\
\hline & inferior & superior & Diferença & inferior & superior & Diferença \\
\hline $1 \ldots \ldots$ & 278 & 725 & $447^{* *}$ & 2600 & 4250 & $1650^{* * *}$ \\
\hline 2. & 1880 & 4650 & $2770 * *$ & 2110 & 4050 & $1940^{* *}$ \\
\hline 3. & 2295 & 7100 & $480 \div * *$ & 2435 & 6725 & $4290^{* *}$ \\
\hline 4. & 2800 & 9100 & $6300^{* *}$ & 3190 & 8500 & $5310 * *$ \\
\hline Média ... & 1813,3 & 5393,7 & & 2583,8 & 5881,2 & \\
\hline
\end{tabular}

As inoculações feitas na face superior deram maior número de lesões do que quando feitas na face inferior. Estes resultados foram semelhantes para os dois vírus.

\section{4 - DISCUSSÃO}

As variedades de feijoeiro ensaiadas mostraram vários graus de suscetibilidade aos vírus de vira-cabeça e da necrose branca. Entre mais de 200 variedades provadas, maior número se mostrou suscetível ao vírus da necrose branca do que ao de vira-cabeça, não tendo havido correlação entre a suscetibilidade aos dois vírus. A variedade Manteiga, entretanto, mostrou-se altamente suscetível a ambos. 
Variedades de feijoeiro suscetíveis ao vírus da necrose branca mostram diferenças no número de lesões formadas por área e na maneira de crescimento destas. A variedade Manteiga desenvolve grande número de lesões, mas elas permanecem pequenas, ao passo que em muitas outras variedades que formam menor número de lesões por área, o crescimento destas é mais rápido. Além das diferenças na conformação das lesões entre diferentes variedades de feijoeiro, foi notado que estirpes diferentes do vírus induzem o aparecimento de lesões de conformação diferente. Estudos de variedades de feijoeiro como hospedeiras diferenciais para estirpes do vírus da necrose branca estão sendo feitos.

Houve também certa diferença entre os sintomas observados nas diferentes variedades de feijoeiro, quando inoculadas com o vírus de vira-cakeça. Tais diferenças não foram, entretanto, da mesma magnitude, como no caso do vírus da necrose branca, mas poderão eventualmente servir para diferençação de estirpes do vírus; neste caso consistiram principalmente na formação de lesões apenas cloróticas e na formação de lesões com tendência para necrose.

É interessante mencionar que a variedade Manteiga, que é bastante suscetível aos vírus de vira-cabeça e da necrose branca, não apresenta lesões locais quando inoculada com o vírus do mosaico comum do fumo (Marmor tabaci $\mathrm{H}$.), sendo imune a êste (25). Esta observação foi confirmada neste laboratório e parece indicar que os fatôres responsáveis pela suscetibilidade a essas duas moléstias são também diferentes daqueles responsáveis pela suscetibilidade ao mosaico comum do fumo. A imunidade da variedade Manteiga ao vírus do mosaico comum do fumo permite o seu uso como planta-filtro para separar o vírus de vira-cabeça e o da necrose branca de misturas com o vírus de mosaico comum do fumo. Êsses resultados já foram obtidos neste laboratório com misturas naturais do vírus de vira-cabeça e do mosaico comum, e com uma mistura feita em laboratório do vírus da necrose branca e do mosaico comum.

Está claro que a inoculação dêstes dois vírus em feijoeiros da variedade Manteiga poderia ser utilizada para separá-los também de outros vírus que não infetam o feijoeiro, sendo êsse fato de bastante interêsse visto se tratar de vírus de propriedades fracas e, portanto, difíceis de serem separados de misturas com outros vírus que têm maior resistência.

$\mathrm{O}$ fato de muitas variedades de feijoeiro se mostrarem imunes ao vírus de vira-cabeça e da necrose branca, bem como ao vírus do mosaico comum do fumo (25), mostra bem a necessidade de se inocularem muitas variedades de uma mesma espécie, nos estudos do círculo de hospedeiras dos diferentes vírus. Caso apenas uma ou outra variedade seja ensaiada, como é feito na maioria dos 
casos, corre-se o risco de se obter conceito errôneo sôbre a suscetibilidade da espécie, se coincidir seja imune a variedade ensaiada.

Os feijoeiros são capazes de permitir a multiplicação de numerosos vírus pertencentes a grupos não relacionados. $O$ conjunto de variedades desta espécie constitui, portanto, verdadeiro reservatório onde se pode esperar encontrar variedades que produzam lesões locais quando inoculadas com grande número dos vírus transmissíveis mecânicamente. O fato de certas espécies, como o feijoeiro, permitirem a multiplicação de grande número de vírus, sugere que elas possuem grande parte dos precursores necessários para a multiplicação de tais vírus, ou que seus sistemas genéticos, controladores da síntese de proteinas, se submetem fàcilmente à interferência dos vírus que penetram em suas células e que passam a controlar parte do sistema, dirigindo-o na síntese de proteína vírus. E, pois, de interêsse que nos estudos de vírus transmissíveis mecânicamente seja sempre experimentada uma coleção representativa de variedades de feijoeiro, pois há bastante possibilidade de que alguma destas possa servir como planta-teste para lesão local.

Há certa diferença de opinião entre os investigadores, sôbre - efeito de substâncias adicionadas às preparações de vírus que inibem ou estimulam a atividade dêste, quando esta é medida pelo número de lesões locais que a preparação causou $(27,28)$. Alegam alguns que o efeito é sôbre o vírus, mas a maior parte acredita que o efeito é sôbre a planta hospedeira. Nos experimentos aqui relatados a extração do inóculo em presença de vários diluentes indicou que a ação pode ser sôbre a planta-teste ou sôbre a preparação de vírus. $O$ efeito sôbre a preparação pode também ser indireto em relação ao vírus, isto é, preservando sua atividade que poderia ser diminuida por substâncias liberadas ou formadas durante a extração do inóculo.

Quando o inóculo da necrose branca foi extraído em presença de água, nenhuma atividade pôde ser constatada por inoculação em fôlhas de feijoeiro Manteiga. Êsse fato provàvelmente resultou da inativação do vírus na preparação, devido à oxidação, como já tinha sido demonstrado (21). A extração dêste vírus em presença do sulfito de sódio fêz com que as preparações causassem numerosas lesões locais, indicando que êsse agente redutor preservou a atividade do vírus na preparação. $O$ búfer sòzinho não aumentou grandemente a atividade das preparações do vírus da necrose branca, isto porque o búfer não evitou a perda de atividade por oxidação, embora possa ter melhorado a sensitividade da planta. Quando a mistura de sulfito de sódio e búfer foi usada, o número de lesões foi maior do que aquêle obtido com o sulfito sòzinho, indicando que o sulfito de sódio preservou a atividade do vírus e a presença do búfer na preparação melhorou a sensitividade da planta-teste. 
0 vírus de vira-cabeça também é sensitivo à oxidação durante a extração e armazenamento in vitro, como já foi demonstrado em uma série de trabalhos por pesquisadores da Austrália (1, 6, 8, 23). Nas presentes experiências houve aumento no número de lesões locais obtidas com preparações do vírus de vira-cabeça extraídas em presença de sulfito de sódio, quando êsse número foi comparado com o de preparações extraídas em presença de água. $\mathrm{O}$ aumento obtido com êsse agente redutor foi, entretanto, menor do que no caso do vírus da necrose branca, indicando que o vírus de viracabeça não foi tão sensível à oxidação como o da necrose branca. $O$ inóculo extraído em presença de búfer apresentou aumento elevado no número de lesões, mostrando que a sensitividade da planta toi bastante melhorada. Quando o sulfito de sódio e o búfer foram misturados, o número de lesões obtido foi menor do que aquêle obtido com búfer sòzinho. Êsse fato não está bem explicado, mas pode indicar que a adição de sulfito ao búfer, embora possa ter reduzido a perda de atividade devido à oxidação, diminuiu bastante a eficiência do búfer em aumentar a sensitividade da planta-teste.

Nas presentes experiências e em outras realizadas com combinações de vírus e plantas-teste diferentes, tem sido notado pelo autor que o efeito do búfer de fosfato é mais importante sobretudo quando a planta-teste é leguminosa ( Phaseolus, Vigna, Dolichos, etc.). $O$ uso de sulfito de sódio $0,02-0,01 \mathrm{M}$ em búfer de fosfato $0,05-0,01 \mathrm{M}$ com $\mathrm{pH} 7$ é hoje operação de rotina neste laboratório, sendo empregado na extração de todo inóculo. Desde que a adição dêsse diluente passou a ser rotina, foi notada grande melhoria nos ensaios de transmissão. A fim de facilitar a preparação diária da solução de sulfito, pesam-se papelinhos com a quantidade de sulfito necessária para obter a concentração desejada, assim como se faz nas farmácias. No momento de preparar o diluente, mistura-se primeiramente o búfer a partir de soluções estoques de $\mathrm{Na}_{2} \mathrm{HPO}_{4}$ e $\mathrm{KH}_{2} \mathrm{PO}_{4}$ e depois se dissolve neste a quantidade de sulfito de um papelinho.

As inoculações efetuadas na face superior da fôlha do feijoeiro Manteiga deram maior número de lesões do que quando feitas na face inferior. Êsse resultado é diferente daquele obtido com o vírus causador do amarelo (Corium betae H.) da beterraba (Beta vulgaris L.), que causou maior número de lesões locais quando inoculado na face inferior da fôlha (14). Desconhece-se, no caso de feijoeiros Manteiga inoculados com os dois vírus, se o menor número de lesões obtido na face inferior da fôlhà indica menor suscetibilidade dos tecidos dessa região ou se resulta do fato de ser mais difícil de nela se aplicar uniformemente o inóculo, devido a serem as nervuras salientes nessa face da fôlha.

O condicionamento das plantas-teste no escuro, por um período de 48 horas precedendo à inoculação, aumentou bastante a susceti- 
bilidade das fôlhas do feijoeiro Manteiga quando inoculadas com o vírus de vira-cabeça. Fato semelhante já tinha sido verificado para plantas de fumo inoculadas com o vírus de "tomato spotted wilt" (1) e para outras plantas-teste inoculadas com outros vírus $(2,3)$. No caso do vírus da necrose branca, devido ao condicionanamento no escuro houve pequeno aumento no número de lesões em alguns ensaios, efeito mais significante em outros e ligeira diminuição em um. Os resultados, de uma maneira geral foram menos significantes do que para o vírus de vira-cabeça. Para os trabalhos quantitativos com os vírus de vira-cabeça e da necrose branca, usando-se o feijoeiro Manteiga não é necessário condicionar as plantas-teste sob luz reduzida antes da inoculação, pois plantas desta variedade são bastante sensitivas șem êsse tratamento.

\section{A BEAN VARIETY USEFUL AS A LOCAL-LESION TEST PLANT FOR TOMATO SPOTTED WILT AND BRAZILIAN TOBACCO STREAK VIRUSES}

\section{S U M M A R Y}

Out of 200 bean varieties tested, plants of the var. Manteiga were the most sensitive to tomato spotted wilt (TSW) and Brazilian tobacco streak (BTS) viruses. The inoculated plants developed local chlorotic spots adequate for counts within 3-6 days after inoculation with the TSW virus; pin point or rings in 2-4 days following inoculation with the BTS virus. Bean plants with the primary leaves $2 / 3$ expanded or slightly older gave better results for the TSW virus, whereas they were more sensitive to BTS virus when $2 / 3$ expanded or slightly younger.

The TSW virus did not become systemic in the bean plants. Most strains of the BTS virus also did not become systemic in the inoculated plants. A yellow strain of this virus usually did.

Sodium sulfite at $0.01 \mathrm{M}$ added to the infected tissues during extraction of the inoculum increased the number of lesions formed in the bean leaves inoculated with the TSW virus; the increase was greater when extraction was made in presence of phosphate buffer at $\mathrm{pH} 7$ and at the concentration of $0.1 \mathrm{M}$. $\mathrm{A}$ mixture of buffer and sulfite did not cause a greater increase than buffer alone.

Por the BTS virus the addition of sodium sulfite at $0.01 \mathrm{M}$ during extraction gave a large increase in the number of lesions; buffer alone caused only a small increase, but a mixture of buffer and sodium sulfite gave the highest increase.

Phosphate buffer at $0.05 \mathrm{M}$ and with $\mathrm{pH} 7$ or 8 , added prior to extraction, gave a higher number of lesions in case of both viruses than the same concentration of buffer at $\mathrm{pH} 5$ or 6 . The use of butter at concentrations ranging from 0.1 to $0.0125 \mathrm{M}$ were tried and did not cause great differences in the number of local lesions, but the best ones seemed to be 0.05 or $0.025 \mathrm{M}$.

Four concentrations of sodium sulfite, $0.1,0.05,0.025$, and $0.0125 \mathrm{M}$ were compared as diluents for the same inocula in presence of phosphate buffer. The two lowest ones gave the highest number of lesions for both viruses.

Bean plants kept for 48 hours under reduced light gave a higher number of lesions than control plants when inoculated with the TSW virus. The increase due to reduced light was smaller when the treated and untreated plants were inoculated with the BTS virus.

Inoculations performed on the upper side of the primary leaves of the bean plants produced more lesions than when they were made on the lower side in case of both viruses. 


\section{LITERATURA CITADA}

1. BALD, J. G. \& SAMUEL, G. Some factors affecting the inactivation rate of the virus of tomato spotted wilt. Ann. appl. Biol. 21:179-190. 1934.

2. BAWDEN, F. C. \& ROBERTS, F. M. The influence of light intensity on the susceptibility of plants of certain viruses. Ann. appl. Biol. 34:286-295. 1947.

3.

Photosynthesis and predisposition of plants to infection with certain viruses. Ann, appl. Biol, 35:418-428. 1948.

4. BERAHA, LOUIS, VARZENDEH, MASSOUD \& THORNBERRY, H. H. Mechanism of the action of abrasives on infection by tobacco mosaic virus. Virology 1:141-151. 1955.

5. BERKELEY, G. H. \& PHILLIPS, J. H. H. Tobacco streak. Canad. J. Res. C. 21:181-190. 1943.

6. BEST, R. J. The preservative effect of some reducing systems on the virus of tomato spotted wilt. Austral. J. exp. Biol. med. Sci. 27:1-17. 1939.

7. The relationship between the activity of tobacco mosaic virus suspension and hydrion concentration over the $\mathrm{pH}$ range 5 to 10 . Austral. J. exp. Biol. med. Sci. 14:323-328. 1936.

8. \& SAMUEL, G. The effect of various chemical treatments on the activity of the viruses of tomato spotted wilt and tobacco mosaic. Ann. appl. Biol. 23:759-780. 1936.

9.

The reaction of the viruses of tomato spotted wilt and tobacco mosaic to the $\mathrm{pH}$ value of media containing them. Ann. appl. Biol. 23:509-537. 1936.

10. CLARK, W. M. The determination of hydrogen ions. Baltimore, The Williams \& Wilkins Co., 1928.

11. COSTA, A. S. Beta patellaris, planta-teste para o vírus da necrose branca do fumo. Bragantia 10:[275]-276. 1950.

12. The concentration of the Brazilian tobacco streak virus in infected plants. Phytophatology 42:231-236. 1952.

13. Studies on the Brazilian tobacco streak virus. (em preparo)

14. \& BENNETT, C. W. Studies on mechanical transmission of virus yellows. Phytopathology 45:233-238, 1955.

15. \& FORSTER, R. Lista de hospedeiras de vira-cabeça. Bragantia 3:[347]-366. 1943.

16. __ LIMA, A. R. \& FORSTER, R. Necrose branca, uma moléstia de virus do fumo (Nicotiana tabacum $L$.) e "fumo couve" como sintoma tardio. J. Agron., Piracicaba 3:1-26. 1940.

17. \& PINTO, A. J. D'ANDREA. Vira-cabeça em feijoeiro. (em preparo)

18. DIACHUM, STEPHEN \& VALLEAU, W. D. Nicotiana rustica as a source of tobacco streak virus. Phytopathology 40:128-134. 1950.

19. FORSTER, R. \& COSTA, A. S. Nota preliminar sôbre a moléstia vira-cabeça do fumo. Rev. Agric., Piracicaba 13:1-12. 1938.

20. FULTON, R. W. Hosts of the tobacco streak virus. Phytopathology 38:421428. 1948.

21.

Virus concentration in plants acquiring tolerance to tobacco streak. Phytopathology 39:231-243. 1949. 
22. KAHN, ROBERT P. \& SCHACHTNER, N. D. Further studies on the phosphate effect in plant virus inoculation. Phytopathology 44:494. 1954.

23. SAMUEL, G., BEST, R. J. \& BALD, J. G. Further studies on quantitative methods with two plant viruses. Ann. appl. Biol. 22:508-524. 1935.

24. SILBERSCHMIDT, $K$. A doença vira-cabeça do fumo. Biológico 3:183-184. 1937.

25. $\quad$ KRAMER, M. Brazilian bean varieties as plant indicators for the tobacco-mosaic virus. Phytopathology 31:430-439. 1941.

26. SMITH, K. M. Texbook of plant virus diseases. London, J. \& A. Churchill Ltda., 1937. $615 \mathrm{p}$.

27. THORNBERRY, H. H. Effect of phosphate buffers on infectivity of tobacco mosaic virus. Phytopathology 25:618-627. 1935.

28. YARWOOD, C. E. The phosphate effect in plant virus inoculations. Phytopathology 42:137-143. 1952.

29. ZAUMEYER, W. J. \& THOMAS, H. REX. Red node, a virus disease of beans. Phytopathology 40:832-846. 1950. 


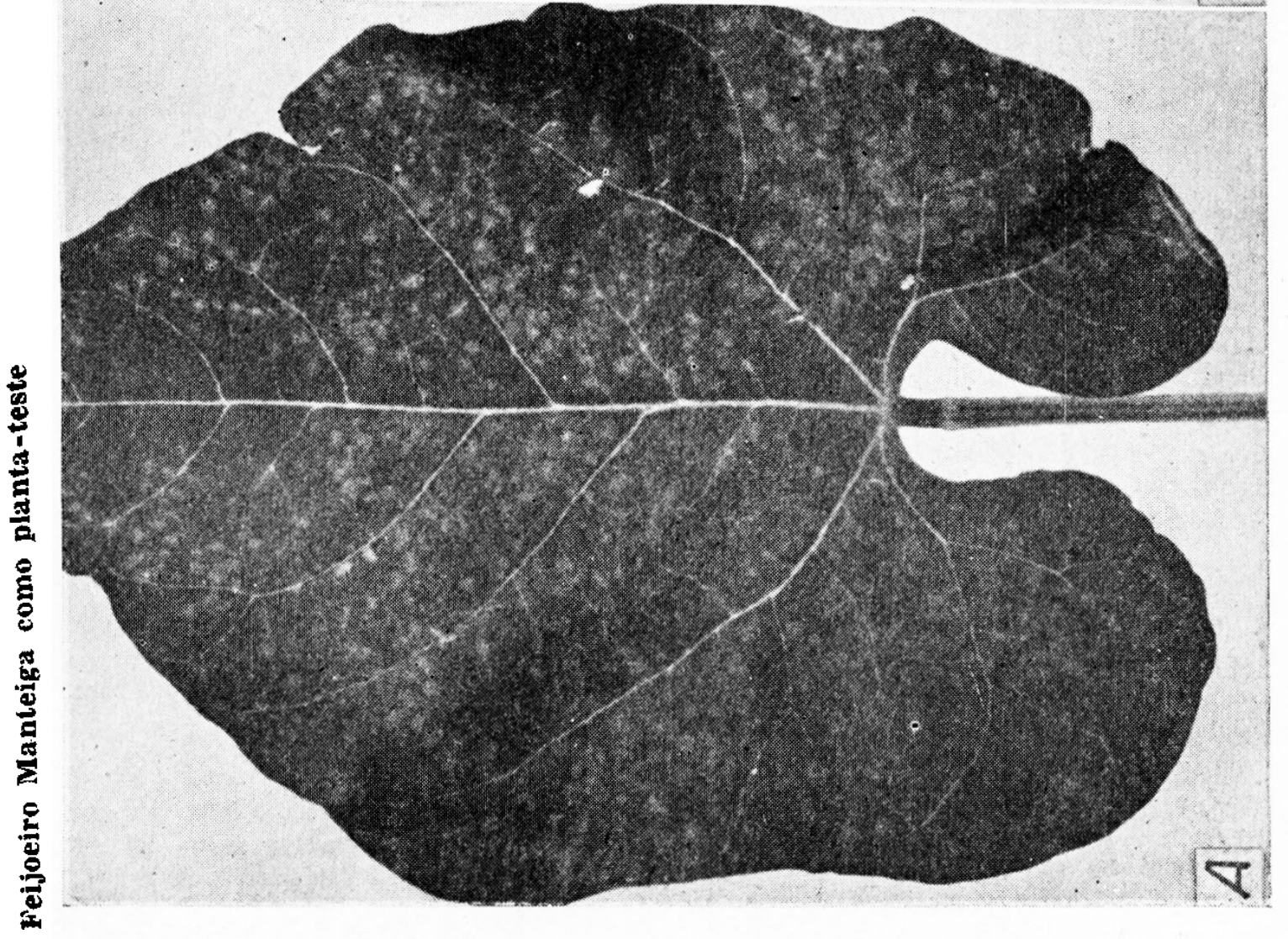




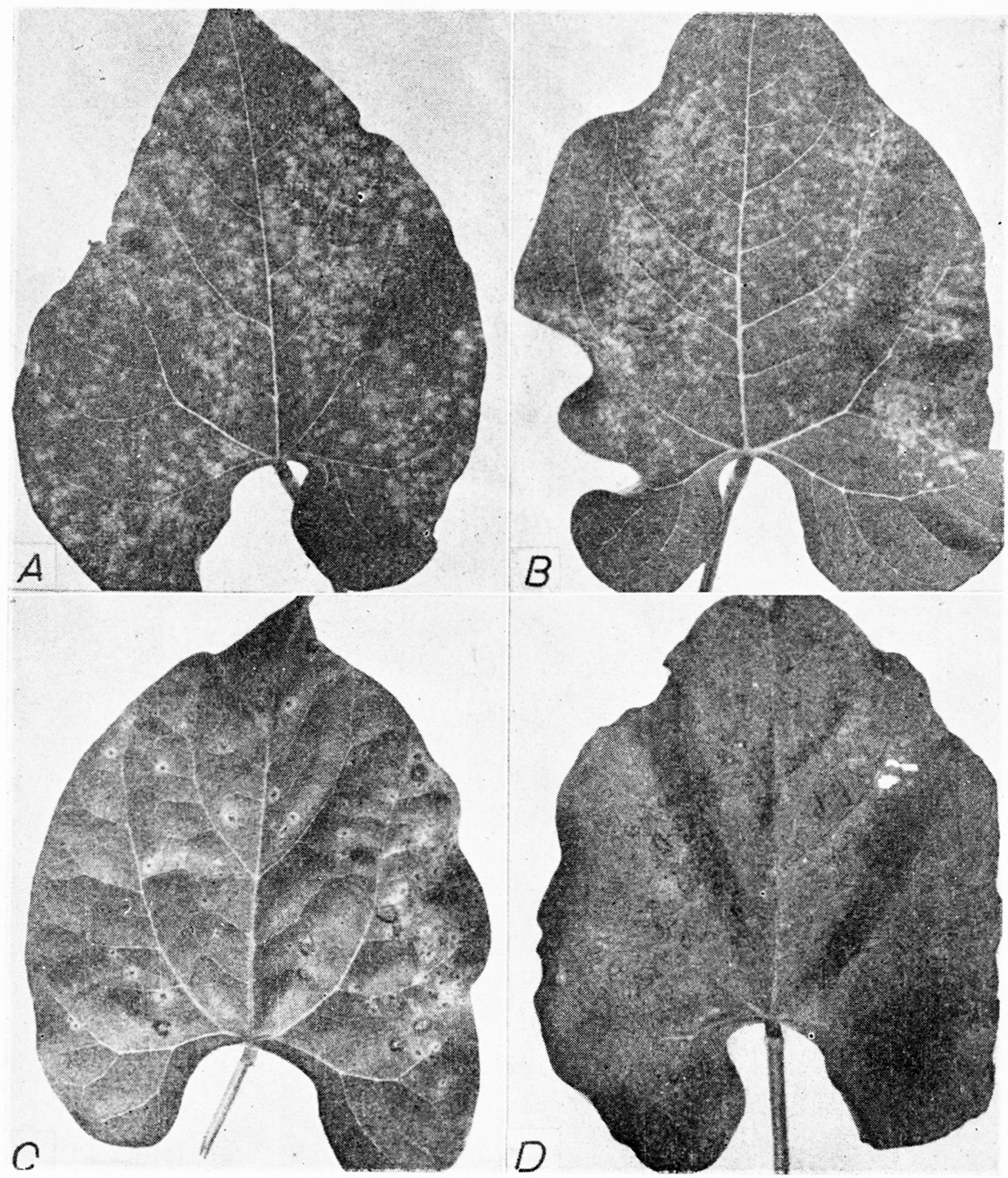

Tipos de lesões locais em fôlhas primárias do feijoeiro. $A$ - Manchas cloróticas, grandes, causadas pelo vírus de vira-cabeça. $B$ - Manchas cloróticas pequenas, causadas por uma estirpe fraca do vírus da necrose branca. $C$ - Pontuações necróticas com halo clorótico, causadas pela mesma estirpe de vírus em Chumbinho. $D$ - Necrose em anéis concêntricos, causada pelo vírus da necrose branca. 